\title{
The donkey skin trade: a growing global problem
}

\section{O comércio de peles de jumento: um problema global em crescimento}

\author{
Laura Skippen $^{1}$ (D); Jonathan Collier²; James Mutiiria Kithuka ${ }^{3}$ \\ ${ }^{1}$ Brooke - Action for Working Horses and Donkeys, London, United Kingdom \\ ${ }^{2}$ Independent researcher, South Queensferry, Edinburgh \\ ${ }^{3}$ Brooke East Africa, Nairobi, Kenya
}

\begin{abstract}
Growing demand for ejiao - gelatin produced from donkey skin and used in Traditional Chinese Medicine - is putting global donkey populations at risk and threatening the livelihoods of millions of people that depend on them in lower and middle-income countries. Hundreds of thousands of donkeys are slaughtered for their skins and exported annually, mostly from Africa to China. However, the trade is spreading across the globe, including Brazil. This article highlights the appalling welfare conditions for donkeys caught up in both the legal and illegal trade, as well as the effects on vulnerable people and the potential for disease spread and hazards to human health.
\end{abstract}

Keywords: Donkey. China. Donkey hides. Welfare. Livelihoods.

\section{RESUMO}

A crescente demanda por ejiao - uma gelatina produzida a partir da pele de jumento e usada na medicina tradicional chinesa - está colocando em risco as populações globais de jumentos e ameaçando a subsistência de milhões de pessoas que dependem delas em países de renda média e baixa. Centenas de milhares de jumentos são abatidos para obter suas peles e exportados anualmente, principalmente da África para a China. No entanto, o comércio está se espalhando pelo globo, inclusive para o Brasil. Este artigo destaca as péssimas condições de bem-estar para os jumentos apanhados no comércio legal e ilegal, bem como os efeitos sobre as pessoas vulneráveis e o potencial de propagação de doenças e riscos para a saúde humana.

Palavras-chave: Jumento. China. Peles de jumento. Bem-estar. Meios de vida.

\section{Correspondence to:}

Laura Skippen

Brooke - Action for Working Horses and Donkeys

The Hallmark Building, 52-56 Leadenhall Street

London EC3A 2BJ, UK

e-mail: laura.skippen@thebrooke.org

Received: September 30, 2020

Approved: February 04, 2021

How to cite: Skippen L, Collier J, Kithuka JM. The donkey skin trade: a growing global problem. Braz J Vet Res Anim Sci. 2021;58(special issue):e175262. https:// doi.org/10.11606/issn.1678-4456.bjvras.2021.175262

The role played by livestock in providing a crucial source of nutrition and income for smallholder farmers globally is well documented (Herrero et al., 2013). Less well acknowledged is the role played by working livestock, in particular the donkey. Donkeys are vital in providing transport of goods and people, access to water for households, including other livestock, and as a valuable source of income (Kenya Agriculture and Livestock Research Organization, 2019; Brooke, 2015) for an estimated 600 million people in low and middle-income countries (LMIC).

Growing demand for ejiao, gelatin produced from donkey skin and used in Traditional Chinese Medicine (TCM) and cosmetic products, is putting global donkey populations at risk. In a study published in 2019 by the Kenya Agricultural and Livestock Research Organization (KALRO), the annual number of donkeys slaughtered in Kenya was five times higher than the annual donkey population growth rate which, if neither rate changed, would lead to the complete extinction of the Kenyan donkey population by 2023 (Kenya Agriculture and Livestock Research Organization, 2019). The trade also threatens the livelihoods of vulnerable 
communities, particularly women, who will often be left carrying the load that a donkey would have (Carder et al., 2019; Brooke, 2014). Smallholder farmers lose an average of USD 109.73 per month for every donkey they lose through sale or theft (Brooke, 2019) with many families unable to send children to school or pay medical bills due to loss of income.

Donkeys are sentient beings with physical and emotional needs specific to their species. The Terrestrial Animal Health Code chapter 7.1 (World Organisation for Animal Health, 2019b) outlines guiding principles for animal welfare, including the responsibilities of owners and handlers towards animals, in fostering positive relationships and taking into account specific species needs. Intensive donkey farming is a relatively recent occurrence. Knowledge is limited about donkey breeding management and intensive farming systems. Currently, the management of large herds is challenging and there is a high risk of disease spread on farms (Bennett \& Pfuderer, 2020) where disease outbreaks are also difficult to contain and result in high mortality (Yang et al., 2018).

A frequently asked question is why donkeys should be any different from other livestock species that are bred for slaughter and human consumption, assuming sufficient welfare regulations are adhered to. One answer is that donkeys don't lend themselves to intensive farming, with a long and unreliable gestation period and a low reproductive rate (Canisso et al., 2019; Carluccio et al., 2015; Fielding, 1988; Galisteo \& Perez-Marin, 2010; Miragaya et al., 2018; Renner-Martin et al., 2009). Large-scale donkey farming is also incompatible with donkeys' intricate health and welfare needs (Brooke, 2020a). Donkeys have complex nutritional needs and a tendency to hide symptoms of pain and distress (The Donkey Sanctuary, 2018), making it difficult to assess their welfare. This means that significant expertise is required to ensure that the high welfare needs of farmed donkeys are met. This includes consideration of their emotional needs such as pair-bonding, a recognized social preference that if not met, may be detrimental to the animal's welfare (Murray et al., 2013).

While some donkeys are farmed for milk and meat, this is rare in comparison to their use as a traction animal (Bennett \& Pfuderer, 2020). Such little value is placed upon the meat carcass that there is little economic sense in keeping animals well-nourished and disease-free before slaughter. Many cases have been reported where donkeys destined for slaughter have been left to starve, as the skin remains in a usable condition (The Donkey Sanctuary, 2017).

In China, the national donkey herd was reduced from 11.6 million in 1992 to 2.6 million in 2019 (The Donkey
Sanctuary, 2019b), yet the ejiao industry needs approximately 4.8 million donkeys skins annually to feed current demand. Ejiao companies have had to look globally to source the majority of their raw material and so far, Africa has been paying the price for this. In Kenya, where bilateral agreements between China and the government have meant donkey slaughter occurred legally until recently, the donkey population has plummeted by over a third since 2010 (The Donkey Sanctuary, 2019b). Cross-border smuggling - often of stolen animals - from neighboring countries that have bans in place has been extensive (A. Hailemariam, personal communication, May 2020).

For the donkey, the trade is a welfare catastrophe. Over 180 countries are members of the OIE and should adhere to international standards for animal welfare during transport and slaughter (World Organisation for Animal Health, 2019b), but these are routinely flouted in the legal trade, before and during slaughter (The Donkey Sanctuary, 2017). Animals are transported for hundreds of miles in overcrowded and airless conditions, without food and water (The Donkey Sanctuary, 2017). Injured, sick, and late-stage pregnant animals are all transported in contravention of OIE guidelines (The Donkey Sanctuary, 2019b). An internal study commissioned by Brooke in 2017 revealed that significant welfare violations occurred during transportation of live donkeys for trade, with selfmutilation, kick injuries and bite wounds commonly seen on arrival at slaughterhouses. Also, there are multiple reports of dead and dying donkeys being found on large consignments of animals (The Donkey Sanctuary, 2017).

A study in Kenya found that gazetted slaughterhouses were recording the slaughter of more donkeys than the number of humane stunning bullets procured (Kenya Agriculture and Livestock Research Organization, 2019), suggesting that large numbers of donkeys are killed without stunning, in defiance of international animal welfare standards (World Organisation for Animal Health, 2019b). Footage from a slaughterhouse in Tanzania (The Donkey Sanctuary, 2019b) shows live donkeys dragged by chains and hit with hammers in full view of other animals awaiting the same treatment, which again contravenes the Terrestrial Animal Health Code chapter 7.5 (World Organisation for Animal Health, 2019b).

The illegal trade, where donkeys are stolen and transported miles on foot or slaughtered and skinned in the bush, is just as disastrous for animal welfare (The Donkey Sanctuary, 2017). It is also a public health hazard, with carcasses left to rot in the open, contaminating water sources and acting as a source of infection to other animals, wildlife, and potentially people (The Donkey Sanctuary, 2019b). 
While Africa remains the primary source of both legally and illegally-sourced donkey hides to China, the trade is spreading across the globe. Brazil has become a target due to the large feral donkey population. In 2018, the Brazil donkey trade was exposed when a holding facility with 700 donkeys in Bahia was shut down due to appalling welfare conditions, with more than 200 donkey carcasses found among the living animals (The Donkey Sanctuary, 2019a) that had no food and whose only water source had been contaminated by the remains of their companions. A nearby abattoir confirmed holding a license to export donkey skins and that it was slaughtering up to 250 donkeys a day (The Donkey Sanctuary, 2019a).

The donkey skins trade has already contributed to transboundary disease outbreaks (World Organisation for Animal Health, 2019a). In early 2019, an equine influenza outbreak in the naïve donkey herd in West Africa led to tens of thousands of deaths in a population that had already been decimated by the trade. A disease outbreak like this, in a region with a large sports horse population such as South America, would be catastrophic for this industry, necessitating movement restrictions, import/export bans, and competition cancellations. Many other more deadly and potentially zoonotic diseases could be spread through both the legal and illegal trade including glanders, anthrax, West Nile virus, and Crimea-Congo Hemorrhagic fever meaning this trade poses a significant public health risk. The global COVID-19 pandemic, which originated from animal species (Zhou et al., 2020), is a reminder that zoonotic disease risks are real and cannot be ignored.

\section{References}

Bennett R, Pfuderer S. The potential for new donkey farming systems to supply the growing demand for hides. Animals (Basel). 2020;10(4):718-39. http://dx.doi.org/10.3390/ ani10040718. PMid:32326062.

Brooke Action for Working Horses and Donkeys. Invisible helpers: women's views on the contributions of working donkeys, horses and mules to their lives [Internet]. 2014 [cited 2020 Sep 26]. Available from: https://www.thebrooke. org/sites/default/files/Advocacy-and-policy/Invisiblehelpers-voices-from-women.pdf.

Brooke Action for Working Horses and Donkeys. Invisible workers: the economic contributions of working donkeys, horses and mules to livehihoods [Internet]. 2015 [cited 2020 Sep 26]. Available from: https://www.thebrooke.org/
A recent ban on slaughterhouses in Kenya after a community-led campaign demonstrates the way forward for tackling the supply of donkey skins to the trade (Brooke, 2020b). By enacting bans the governments of affected countries can squeeze the supply of skins for the ejiao industry. However, legislating for and enforcing change requires commitment. The Kenyan ban has led to a backlash from slaughterhouses, with court action launched against the government. This led to a stay order being granted in one case, allowing the slaughter to continue.

Ultimately, this is an animal health and welfare issue on an enormous scale. As animal health professionals and advocates for the welfare of all animals veterinarians should oppose the trade based on the animal welfare atrocities alone. But there is more to this story. The humanitarian crisis caused by the loss of animals that are critical to the livelihoods of millions of people is all too large to ignore. Those working in animal health and welfare must collaborate to identify partners concerned with the human health and welfare risks created by the demand for donkey skins and work together to bring this destructive trade to a permanent halt.

\section{Conflict of Interest}

No competing interests have been declared by the authors.

\section{Ethics Statement}

This article is a review article and as such did not require ethical approval or informed consent.

sites/default/files/Advocacy-and-policy/Invisible-workersreport-2020.pdf.

Brooke Action for Working Horses and Donkeys. The donkey skin trade: policy brief on the worldwide impact [Internet]. 2019 [cited 2020 Sep 26]. Available from: https:// www.thebrooke.org/sites/default/files/Brooke Donkey Skin Policy Brief.pdf.

Brooke Action for Working Horses and Donkeys. Factsheet: breeding for the donkey skin trade [Internet]. 2020a [cited 2020 Sep 26]. Available from: https://www.thebrooke.org/ sites/default/files/Advocacy-and-policy/Farming\%20and\%20 Breeding\%20Fact\%20Sheet.pdf.

Brooke Action for Working Horses and Donkeys. The donkey skin trade [Internet]. 2020b [cited 2020 Sep 26]. 
Available from: https://www.thebrooke.org/our-work/ donkey-skin-trade.

Canisso IF, Panzani D, Miró J, Ellerbrock RE. Key aspects of donkey and mule reproduction. Vet Clin North Am Equine Pract. 2019;35(3):607-42. http://dx.doi.org/10.1016/j. cveq.2019.08.014. PMid:31672204.

Carder G, Ingasia O, Ngenoh E, Theuri S, Rono D, Langat P. The emerging trade in donkey hide: an opportunity or a threat for communities in Kenya? Agric Sci. 2019;10(9):1152-77.

Carluccio A, Gloria A, Veronesi M, De Amicis I, Noto F, Contri A. Factors affecting pregnancy length and phases of parturition in Martina Franca jennies. Theriogenology. 2015;84(4):6505. http://dx.doi.org/10.1016/j.theriogenology.2015.04.027. PMid:26007611.

Fielding D. Reproductive characteristics of the jenny donkey - Equus asinus: a review. Trop Anim Health Prod. 1988;20(3):161-6. http://dx.doi.org/10.1007/BF02240085. PMid:3057709.

Galisteo J, Perez-Marin C. Factors affecting gestation length and estrus cycle characteristics in Spanish donkey breeds reared in southern Spain. Theriogenology. 2010;74(3):44350. http://dx.doi.org/10.1016/j.theriogenology.2010.02.027. PMid:20451997.

Herrero M, Grace D, Njuki J, Johnson N, Enahoro D, Silvestri $\mathrm{S}$, Rufino MC. The roles of livestock in developing countries. Animal. 2013;7(Suppl 1):3-18. http://dx.doi.org/10.1017/ S1751731112001954. PMid:23121696.

Kenya Agriculture and Livestock Research Organization - KALRO. The status of donkey slaughter in Kenya and its implications on community livelihoods [Internet]. 2019 [cited 2020 Sep 26]. Available from: https://www. thebrooke.org/sites/default/files/Kalro Report-Final.pdf.

Miragaya MH, Neild DM, Alonso AE. A review of reproductive biology and biotechnologies in Donkeys. J Equine Vet Sci. 2018;65:55-61. http://dx.doi.org/10.1016/j.jevs.2017.12.005.

Murray L, Byrne K, D'Eath R. Pair-bonding and companion recognition in domestic donkeys, Equus asinus. Appl Anim Behav Sci. 2013;143(1):67-74. http://dx.doi.org/10.1016/j. applanim.2012.11.005.

Renner-Martin TF, Forstenpointner G, Weissengruber GE, Eberhardt L. Gross anatomy of the female genital organs of the domestic donkey (Equus asinus Linné, 1758).
Anat Histol Embryol. 2009;38(2):133-8. http://dx.doi. org/10.1111/j.1439-0264.2008.00911.x. PMid:19007353.

The Donkey Sanctuary. Under the Skin: The emerging trade in donkey skins and its implications for donkey welfare and livelihoods [Internet]. 2017 [cited 2020 Sep 26]. Available from: https://www.thedonkeysanctuary.org.uk/sites/uk/ files/2017-11/under_the_skin_report.pdf.

The Donkey Sanctuary. The clinical companion of the donkey [Internet]. 2018 [cited 2020 Sep 26]. Available from: https://www.thedonkeysanctuary.org.uk/sites/uk/ files/2018-03/the-clinical-companion-of-the-donkey.pdf.

The Donkey Sanctuary. Help for 700 donkeys destined for the skin trade [Internet]. 2019a [cited 2020 Sep 26]. Available from: https://www.thedonkeysanctuary.org.uk/ news/help-for-700-skin-trade-donkeys-dying-in-brazil.

The Donkey Sanctuary. Under the skin: update on the global crisis for donkeys and the people who depend on them [Internet]. 2019b [cited 2020 Sep 26]. Available from: https:// www.thedonkeysanctuary.org.uk/sites/uk/files/2019-12/ under-the-skin-report-english-revised-2019.pdf.

World Organisation for Animal Health - OIE. Equine influenza, Nigeria [Internet]. 2019a [cited 2020 Sep 26]. Available from: https://www.oie.int/wahis_2/public/wahid.php/Reviewreport/ Review?page_refer=MapFullEventReport\&reportid=29135.

World Organisation for Animal Health - OIE. Terrestrial Animal Health Code [Internet]. 2019b [cited 2020 Sep 26]. Available from: https://www.oie.int/en/standard-setting/ terrestrial-code/.

Yang H, Xiao Y, Meng F, Sun F, Chen M, Cheng Z, Chen Y, Liu S, Chen H. Emergence of H3N8 equine influenza virus in donkeys in China in 2017. Vet Microbiol. 2018;214:1-6. http:// dx.doi.org/10.1016/j.vetmic.2017.11.033. PMid:29408020.

Zhou P, Yang XL, Wang XG, Hu B, Zhang L, Zhang W, Si HR, Zhu Y, Li B, Huang CL, Chen HD, Chen J, Luo Y, Guo H, Jiang RD, Liu MQ, Chen Y, Shen XR, Wang X, Zheng XS, Zhao K, Chen QJ, Deng F, Liu LL, Yan B, Zhan FX, Wang YY, Xiao GF, Shi ZL. A pneumonia outbreak associated with a new coronavirus of probable bat origin. Nature. 2020;579(7798):270-3. http://dx.doi.org/10.1038/ s41586-020-2012-7. PMid:32015507.

Financial Support: This review article did not receive any funding. 